\title{
A Review of the Relationship between Corporate Entrepreneurship and Financial Performance
}

\author{
Andreeea CHITIMIEA ${ }^{\text {* }}$ \\ Loredana Nicoleta ZAINEA ${ }^{2}$ \\ Cristian MARCU 3 \\ Alexandru PARU 4 \\ Vasile Emil STEFAN 5
}

DOI: $10.24818 / \mathrm{mer} / 2021.06-10$

\begin{abstract}
The correlation between performance and entrepreneurship is researched in a large number of studies over the years. The research is analysing multiple aspects: the position of corporate entrepreneurship in gaining financial performance and also its position next to the other drivers and how corporate entrepreneurship is interconditioned with the others. The research results indicate the strong influence on the financial performance of the corporate entrepreneurship among the major drivers (human resources management, economic environment and digitalization), has confirmed our theory of their interconnectivity and has led us to the conclusion that entrepreneurial orientation includes corporate entrepreneurship, organisational culture, managerial tools in future research can be approached as a single element.

In the development of this study, the authors used two methods of analysis (bibliometric analysis and systematic review) to synthesize and evaluate all published studies collected from the database Web of Science through a planned and structured approach. By realizing a quantitative analysis of the 317 papers using bibliometric analysis and the qualitative one carried out by filtering the papers with systematic review and resulting in a more in-depth analysis of 39 papers, the authors want to contribute to the improvement of literature for future research that can help increase the financial income of European entrepreneurs.
\end{abstract}

KEYWORDS: financial performance, entrepreneurship, drivers, literature review, systematic review

JEL CLASSIFICATION: L25, L26, L29

\section{INTRODUCTION}

The factors and indicators that determine whether an enterprise is successful in the market or not (Walker \& Brown, 2004) have created much controversy in the literature. However, the general opinion is that the financial performance is a significant indicator to determine whether a firm is viable and successful in its current activities (Niewoudt, 2016). Despite numerous studies that deepen this topic, there hasn't been elaborated a unique methodology on how to measure performance (Wiklund, 2006).

\footnotetext{
1* Bucharest University of Economic Studies, Romania, chitimieaandreea14@stud.ase.ro, corresponding author

${ }^{2}$ Bucharest University of Economic Studies, Romania, loredananicoleta.zainea@gmail.com

${ }^{3}$ Bucharest University of Economic Studies, Romania, marcucristian15@ stud.ase.ro

${ }^{4}$ Bucharest University of Economic Studies, Romania, alexandru.paru@gmail.com

${ }^{5}$ Bucharest University of Economic Studies, Romania, vasile.stefan@yahoo.com
} 
A distinction in terms of how to measure the level of performance was made according to the nature of the resources (financial and non-financial). In the non-financial measures there are included self-sufficiency, customer satisfaction, increased employment and job satisfaction, and also the ability of the employees to balance work and family (Walker \& Brown, 2004). In the financial measures most researchers include the financial indicators.

The objective for any business is to use available resources to create a result that can be sold in order to gain profit, which leads to the conclusion that financial performance is an important part of any business. This makes the evaluation of the performance an important process in which the top management closely follows the feedback received on the actions taken so that the company can maintain its competitiveness and increase its profitability (Burja \& Burja, 2013).

In an extremely competitive environment, increasing the profit is the main objective and in order to achieve financial performance companies need to adopt different business strategies depending on the encountered challenges (Abou-Moghli \& Al-Abdallah, 2018).

In the evaluation of a company's performance, a key role is considered to be played by corporate entrepreneurship (CE) (Reijonen et al., 2015). The entrepreneurial efforts of an enterprise depend on corporate entrepreneurship because this style delivers results (Abou-Moghli \& AlAbdallah, 2018). Considering how there is a drastic decrease among enterprises that survive the development stage (Miller \& Miller-Breton, 2011), the trend among the companies that incorporate corporate entrepreneurship is increasing.

Through this study, the authors want to analyze the evolution of the scientific research regarding the relationship between financial performance and corporate entrepreneurship, and to investigate the other drivers of corporate entrepreneurship.

In developing our study, the collected database has been selected from an internationally recognized platform for its quality of its indexed research papers (Web of Science). The study is based on a quantitative analysis done on 317 papers using bibliometric analysis and also a qualitative one (systematic review) carried out on the 39 papers remaining after the filtering process. With this paper results the authors want to contribute to the improvement of literature for future research that can help increase the financial income of European entrepreneurs.

Therefore, after the introduction, the research method is explained, the results of the bibliometric study and systematic review are analysed and at the end, in the conclusion section there are emphasized the main findings.

\section{LITERATURE REVIEW}

Corporate entrepreneurship (intra-entrepreneurship) involves formal and informal activities within the company and is a process used in discovering and developing new business opportunities, products, services or processes through strategic renewal and innovation that create value and generate new growth of income through entrepreneurial thinking and action (Guth \& Ginsberg 1990; Sharma \& Chrisman 1999; Bierwerth et al., 2015; Abou-Moghli \& Al-Abdallah, 2018).

Numerous studies have been done to quantify corporate entrepreneurship and its effects. Studies such as Zahra (1995), Goosen, de Coning \& Smit (2002), Karacaoglu, Bayrakdaroglu \& San 
(2012), Bierwerth et al. (2015), Otache \& Mahmood (2015), Abou-Moghli \& Al-Abdallah (2018), Umrani, Kura \& Ahmed (2018) directly argue that there is a relationship between organizational performance and corporate entrepreneurship or contribute to the reasoning that such a relationship could exist.

However, in a more in-depth analysis of the existing literature showed an inconclusion regarding the relationship between corporate entrepreneurship and business performance (Rauch et al., 2009; Karacaoglu et al., 2013). There are also arguments that contradict the impact of corporate entrepreneurship on business performance (Otache \& Mahmood, 2015). Some researchers have argued that the relationship between corporate entrepreneurship and the financial performance of the enterprise depends on the strategic orientations implemented; namely: the market orientation, nurturing the relationship with the employees and the orientation towards knowledge development and specializing in the field of activity (Wang, 2008; Zhao et al., 2011; Kwak et al., 2013; Seo et al., 2014). Another opinion is that corporate entrepreneurship will have a more significant and positive impact on business performance if it is implemented alongside other strategic business guidelines (Otache \& Mahmood, 2015).

Other researchers also argued that the impact of corporate entrepreneurship on business performance depends on a multitude of different factors, such as organizational structure, economic environment, applied management style, human resource management, organizational culture, and resources and skills. organizational (Burgelman, 1988; Kuratko et al., 2004; Li, Zhao \& Liu, 2006; Rutherford \& Holt, 2007; Gunday et al., 2011; Pantea, Gligor \& Anis, 2014; Senderovitz, Klyver \& Steffens, 2015; Bello et al., 2016; Begonja et al., 2016; Parida et al., 2016 Madison et al., 2018). In addition, in other studies we found that researches have argued that the firms orientation in appllying the entrepreneurial specific agility in reacting to the market does not guarantee superior commercial performance, especially in emerging economies (Otache \& Mahmood, 2015).

Corporate entrepreneurship is a defined as a new management philosophy that encourages the development of strategic agility, flexibility and continuous creativity. Corporate entrepreneurship also aims to transform administrative-oriented employees into employees with entrepreneurial thinking, capable of managing certain situations on their own (Kraus and Kauranen, 2009). Therefore, entrepreneurial orientation is a very important tool in the implementation of corporate entrepreneurship because it captures the inclination of an enterprise towards entrepreneurship. The entrepreneurial orientation it is understood as a process in which companies formulate a culture and inculcate innovation, proactivity, risktaking and competitiveness in their teams (Otache \& Mahmood, 2015).

In corporate entrepreneurship, innovation means managing new ideas, experiments, the originality of creative processes which indicates the organizational offers new and original products, services and processes (Karacaoglu, Bayrakdaroglu \& San, 2012).

Risk-taking reflects the company's desire to explore the unknown and involves allocating resources to projects where the results are unknown and the costs of failure are high (Miller and Friesen, 1978; Wiklund \& Shepherd, 2005). Corporate risk-taking can be conceptualized as the organizational attitude towards applying a new entrepreneurial specific agility for the purpose of corporate profitability and growth by tolerating the estimated probable losses (Karacaoglu, Bayrakdaroglu \& San, 2012).

The concept of proactivity defines the ability of firms to forecast and act on market strategies to capitalize opportunities and meet the demands ahead of the competitors (Lumpkin \& Dess, 1996; Karacaoglu, Bayrakdaroglu \& San, 2012; Schepers et al., 2013). Based on this forward- 
looking perspective, proactive businesses are known to become market leaders if they make the most of the market opportunities and present new products or services ahead of the competition.

Studies on corporate entrepreneurship have shown that entrepreneurial activities within enterprises offer high and successful financial performance (Zahra, 1995; Lumpkin \& Dess, 1996; Barringer \& Bluedorn, 1999; Goosen, by Coning \& Smit, 2002; Karacaoglu, Bayrakdaroglu \& San , 2012; Schepers et al., 2013; Bierwerth et al., 2015; Reijonen et al., 2015; Otache \& Mahmood, 2015; Abu-Moghli \& Al-Abdallah, 2018; Umrani, Kura \& Ahmed, 2018). From these studies it can be deduced a clear conclusion that corporate entrepreneurship has a multidimensional structure that includes: risk taking, innovation, proactivity and competitive aggression (Sharma and Chrisman, 1999; Otache \& Mahmood, 2015).

\section{RESEARCH METHODOLOGY AND DATA COLLECTION}

Two methods of analysis (bibliometric analysis and systematic review) were used in this paper to explore how the impact of corporate entrepreneurship on the financial performance is reflected in research published to date. Through a preliminary analysis of the literature, the authors identified a real interest in the link between corporate entrepreneurship and financial performance, but noted the lack of a synthesis of factors that contribute to increasing financial performance for companies that practice corporate entrepreneurship.

The authors chose to use systematic review to the detriment of other techniques and methodologies due to the fact that this method of analysis evaluates published academic research through a planned and structured approach. The influence of the research questions that the authors want to answer through this paper determined the selection of only the empirical studies. In other words, only the papers that highlight the position of corporate entrepreneurship in increasing the financial performance and show its interconnectivity with the other major drivers that have an impact on the financial performance of an enterprise, were selected. In addition, the use of organized, easy-to-understand, and replicable methods to identify, select, and critically evaluate research relevant to the clearly formulated question (Tranfield, Denyer \& Smart, 2003; Jones, 2004) was another reason for choosing this method of analysis. The objectivity and ease with which this method can be replicated as procedures and the explicit detailing of analysis methods, has led to an increase in the number of papers based on systematic review analyses (Becker, 2004; Crossan \& Apaydin, 2009; Hallinger, 2013; Voorberg, Bekkers \& Tummers, 2015; Bourcet, 2019).

Also, unlike other papers based on systematic reviews, the authors want this detailed review of the papers to generate an analysis and discussion of existing literature to improve the literature and confirm the positive impact of corporate entrepreneurship on the financial performance/success of an enterprise.

The motivation behind the use of a bibliometric analysis is that it appreciates the interest of researchers in a particular field based on quantitative methods (Gonzalez-Loureiro, Dabić \& Furrer, 2015; Dabic et al., 2020). At the same time, this type of analysis is mainly found in papers that seek to assess the correlations made by many specialists between certain specific features of a field (Servantie et al., 2016; Zheng, 2018; Dan \& Goia, 2018; Berbegal-Mirabent, Alegre \& Ribeiro-Soriano, 2018; Dionisio, 2019; Lampe, Kraft \& Bausch, 2019; Gora, 2019, Chițimiea et al, 2020a; Chiţimiea et al, 2020b).

In the current paper, a first step is to determine the keywords. Since the purpose of the article is to determine the impact of corporate entrepreneurship on financial performance, the 
keywords used for this paper were: "entrepreneurship" AND "financial performance" in the Web of Science database in Topic (317 papers).

In the early stages of this paper, some of the criteria have already been pre-established, for example, the selection of papers available in the Web of Science database. The motivation for choosing the Web of Science database is the international recognition of this platform for the quality of indexed papers in different fields (Rey-Martí, Ribeiro-Soriano \& Palacios-Marqués, 2016). The Web of Science (WOS) database contains the most reputable and influential journals and is therefore recognized as the most authoritative source of data for studying publications in any field of interest (Song, Zhang \& Dong 2016; Zhao et al., 2019).

In this analysis we selected the main areas of research and the main areas in which the concepts are studied. We also analysed the years of publication, the identification of early publications and the verification of progress over the years. The database was collected by searching the "topic" of the keywords mentioned above to obtain a wide range of information on the targeted field. The result was the extraction of 317 papers. The selection of papers according to their type (articles, proceedings paper and reviews) was another criterion for delimiting the papers of interest and contributed to the restriction of studies to 314. Following this stage, the authors verified that these papers did not have double indexing. Furthermore, because there were studies in the database in languages other than those of international circulation, only articles published in English were selected (the total number of articles reaching 308).

Based on these results, the following fields were selected as areas of interest: Business Economics, Engineering, Social Sciences, Operations Research Management Science, Environmental Sciences Ecology, Computer Science, Science Technology, Development Studies, Area Studies. This selection led to restricting the database to a total of 292 studies.

These filters, coupled with the authors' decision to demonstrate the impact of corporate entrepreneurship and the methods used by entreprises to increase their financial performance in order to have a successful business, led to the restriction of the database using the keywords. In this step of the research, we found that some papers don't have keywords, but WoS assigned to those papers' keywords known as keywords plus. So, we collected keywords of the authors and the keywords plus assigned by WoS. During this stage, the authors used the VOSviewer software application, which does not require a license and is free of charge to use and/or distribute. The restriction was made by selecting additional keywords used by the authors and those added by WoS (keywords plus), which were used at least 25 times. This stage led to the selection of the following keywords: business performance (30), strategy (31), firms (34), entrepreneurial orientation (34), performance (37), impact (38), innovation (52), management (54), firm performance (60), corporate entrepreneurship (85), competitive advantage (27).

The next step was to check and count the articles in which these keywords are found. Thus, by manually counting the meeting of these keywords added later, it was necessary to establish an additional criterion: that the selected articles have at least 3 keywords from those additionally added by the authors. At this stage, the number of articles was reduced to 117 .

Given that the main objective of this analysis is to demonstrate the interaction between corporate entrepreneurship and financial performance and what impact they had on the success (financial performance) of the company, the authors narrowed the 117 papers by assessing the fulfillment of inclusion criteria (empirical studies). After this filtering, the database led to a number of 60 papers.

By analyzing the abstracts and the paper (where found online) to determine their relevance and searching for the final papers available for download, the database was reduced to a total of 39 
papers remaining to be analysed. All these papers are empirical studies and address the relevant factors in achieving financial performance.

\section{RESULTS}

The results reflect a growing interest in the research of the factors that can influence the business performance and how a business can be successful. At the same time, given that is more common of the employees to become entrepreneurs, we note that since 2006, researchers have also noticed this trend, due to the increase in the number of papers analyzing the profitability of risky decisions and entrepreneurial policies implemented ( $85 \%$ of the 314 papers included in this study were published after 2006) (see Figure 1).

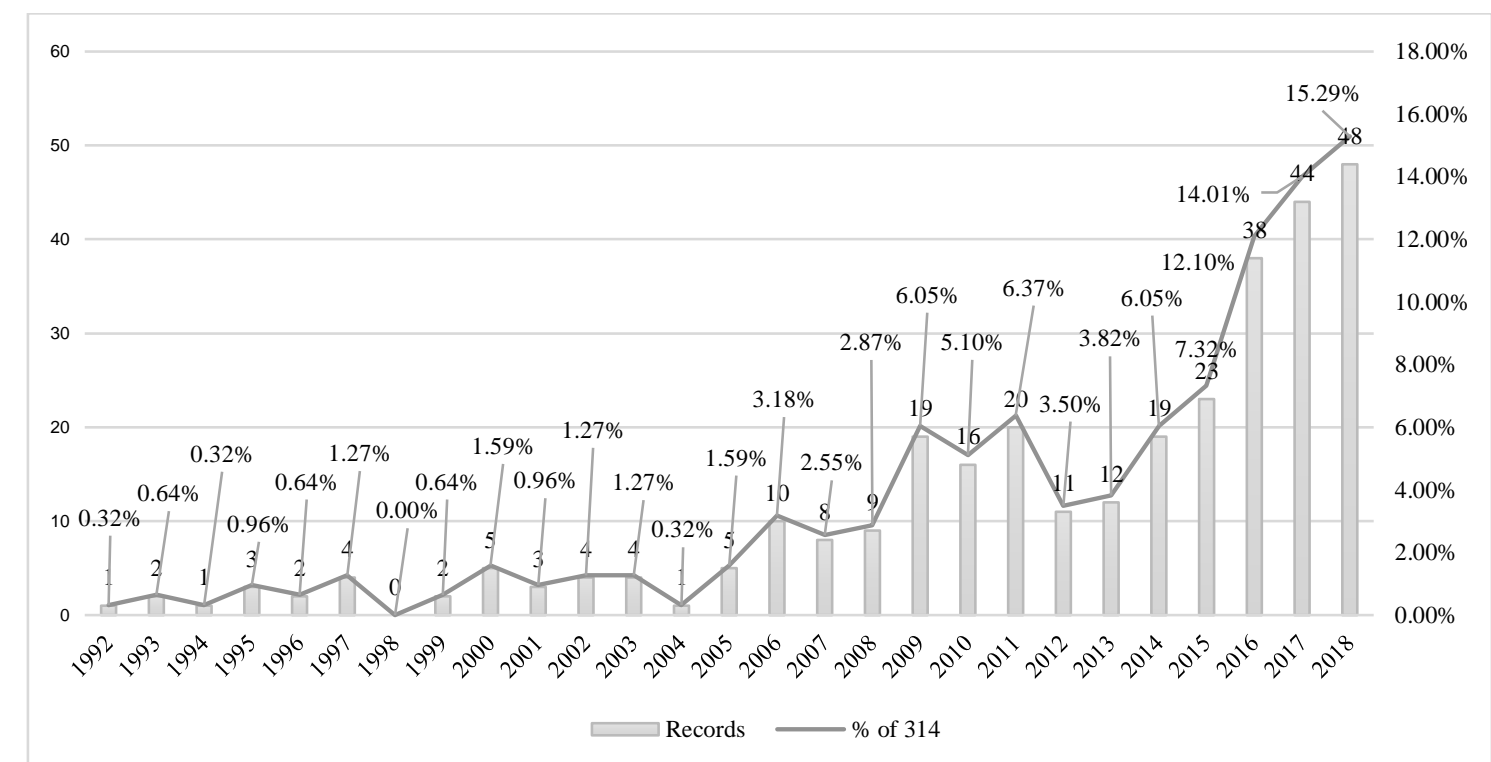

Figure 1. Annual evolution of published papers (number of publications and precent)

Source: made by the authors

Analyzing the journals in which the studies were published, we highlighted the links between journals depending on the field they target through a network map. We conditionate that the power of the link be at least 150 links. Highlighted in Figure 2 are the 46 journals that meet this condition, and which they have been divided into 8 clusters. In this regard, we noticed that areas such as management (nodes highlighted in red), research and development (purple nodes), banking (turqouise nodes), statistics (yellow nodes) have close links and refer to journals that address areas such as economic (green nodes), financial (blue nodes) and accounting (orange nodes). 


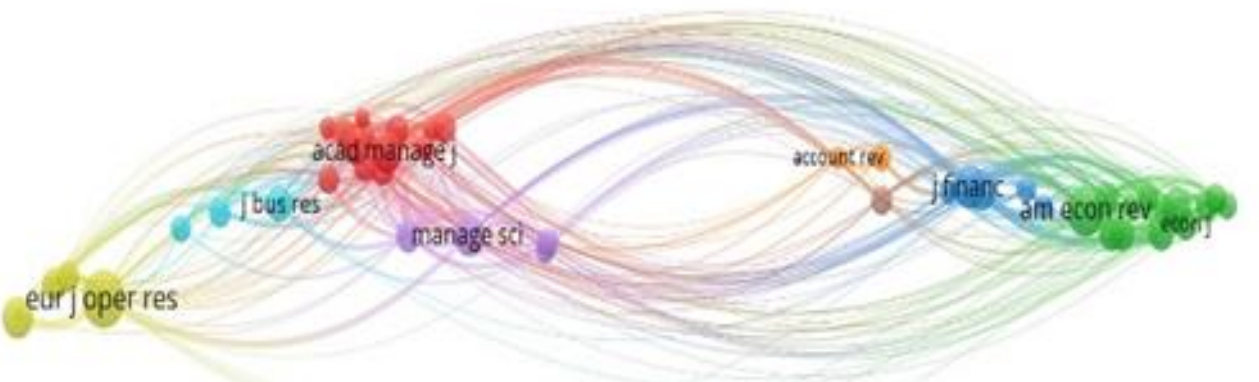

\section{vosviewer}

Figure 2. The journal network mapping

Source: made by the authors with VOSviewer

By far, according to Table 1, among the most published studies are those published by researchers from the USA (31.53\%), England (9.55\%), China (8.60\%), Spain (6.69\%) and Germany (6.05\%). This is understandable given that these regions are among the most economically developed areas. It is worth noting that countries such as the Czech Republic, Norway, Scotland, Austria and Croatia have the fewest publications.

Table 1. Published studies according to the authors nationality

\begin{tabular}{|l|l|l|l|l|l|}
\hline Countries/Regions & records & \% of 314 & Countries/Regions & records & \% of 314 \\
\hline USA & 99 & $31.53 \%$ & Turkey & 10 & $3.18 \%$ \\
\hline England & 30 & $9.55 \%$ & Netherlands & 8 & $2.55 \%$ \\
\hline Peoples R China & 27 & $8.60 \%$ & South Korea & 8 & $2.55 \%$ \\
\hline Spain & 21 & $6.69 \%$ & Finland & 7 & $2.23 \%$ \\
\hline Germany & 19 & $6.05 \%$ & Malaysia & 7 & $2.23 \%$ \\
\hline Australia & 15 & $4.78 \%$ & Czech Republic & 5 & $1.59 \%$ \\
\hline Canada & 15 & $4.78 \%$ & Iran & 5 & $1.59 \%$ \\
\hline Italy & 15 & $4.78 \%$ & Norway & 5 & $1.59 \%$ \\
\hline Belgium & 10 & $3.18 \%$ & Scotland & 5 & $1.59 \%$ \\
\hline France & 10 & $3.18 \%$ & South Africa & 5 & $1.59 \%$ \\
\hline Sweden & 10 & $3.18 \%$ & Austria & 4 & $1.27 \%$ \\
\hline Switzerland & 10 & $3.18 \%$ & Croatia & 4 & $1.27 \%$ \\
\hline
\end{tabular}

Further on we made a cluster chart (figure 3) in which we highlighted the links between these countries based on a minimum number of a record 5 documents. This analysis highlighted on the map the presence of 21 countries, grouped in 7 clusters. The most important clusters are those in the red zone (Australia, Canada, South Korea, Sweden), followed by five clusters grouped each with three regions with strong links between them, namely the green area (Belgium, France, Spain), blue zone (England, Germany, Scotland), yellow zone (China, Malaysia, Norway), purple zone (Finland, Switzerland, Netherlands), turqouise zone (USA, South Africa, Turkey). The lowest contributions are the orange area (Iran, Italy). 
The positioning of countries on the map is given by the strength of the relationship between them, co-citations and links between articles published in collaboration with authors of different citizenship, and the presence of clusters more highlighted or reduced on the map is given by the number of nodes in their vicinity, as well as the strength of the connections.

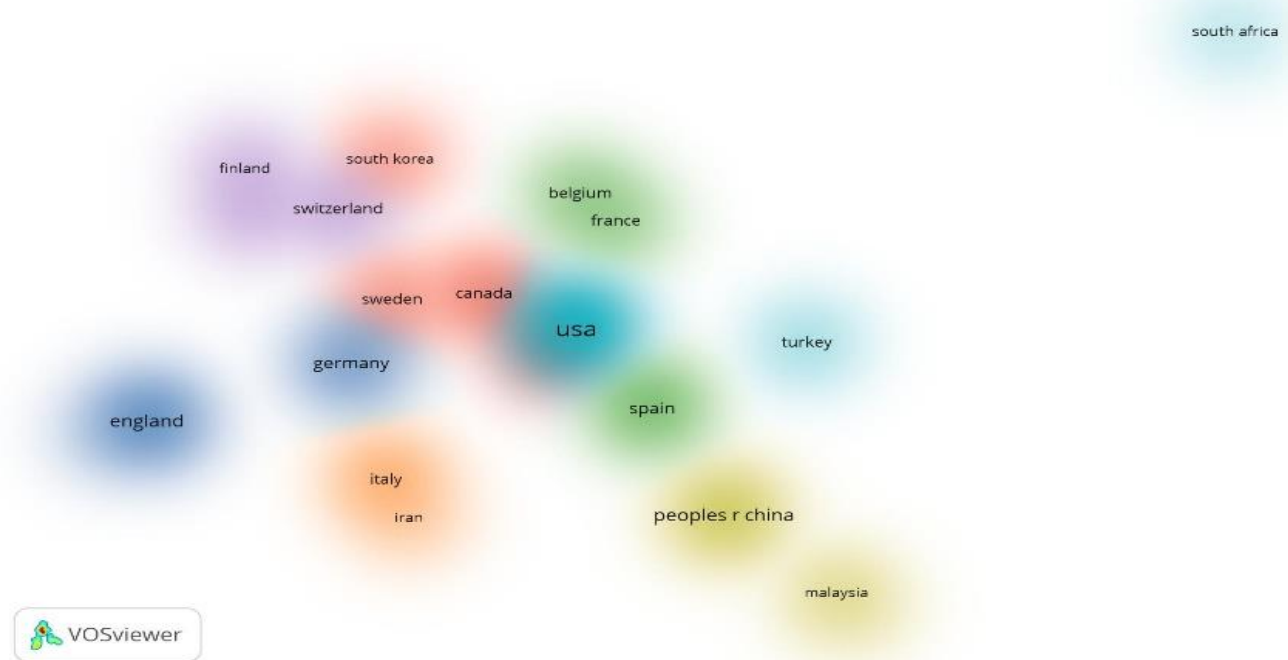

Figure 3. Cluster representation of the countries

Source: made by the authors with VOSviewer

The analysis of keywords based on co-occurrences was highlighted according to the periods in which these keywords were used predominantly. Thus, although keywords are grouped into five clusters, the color of the nodes varies depending on the period of time in which the keyword is used. For example, the words closer to purple ("strategic management", "model", "ownership", "environment", etc.) have been used since 2010, and those such as "business", "entrepreneurial orientation", "knowledge", "dynamic capabilities", "moderating role "(highlighted in yellow) capturing the literature since 2014 (Figure 4).

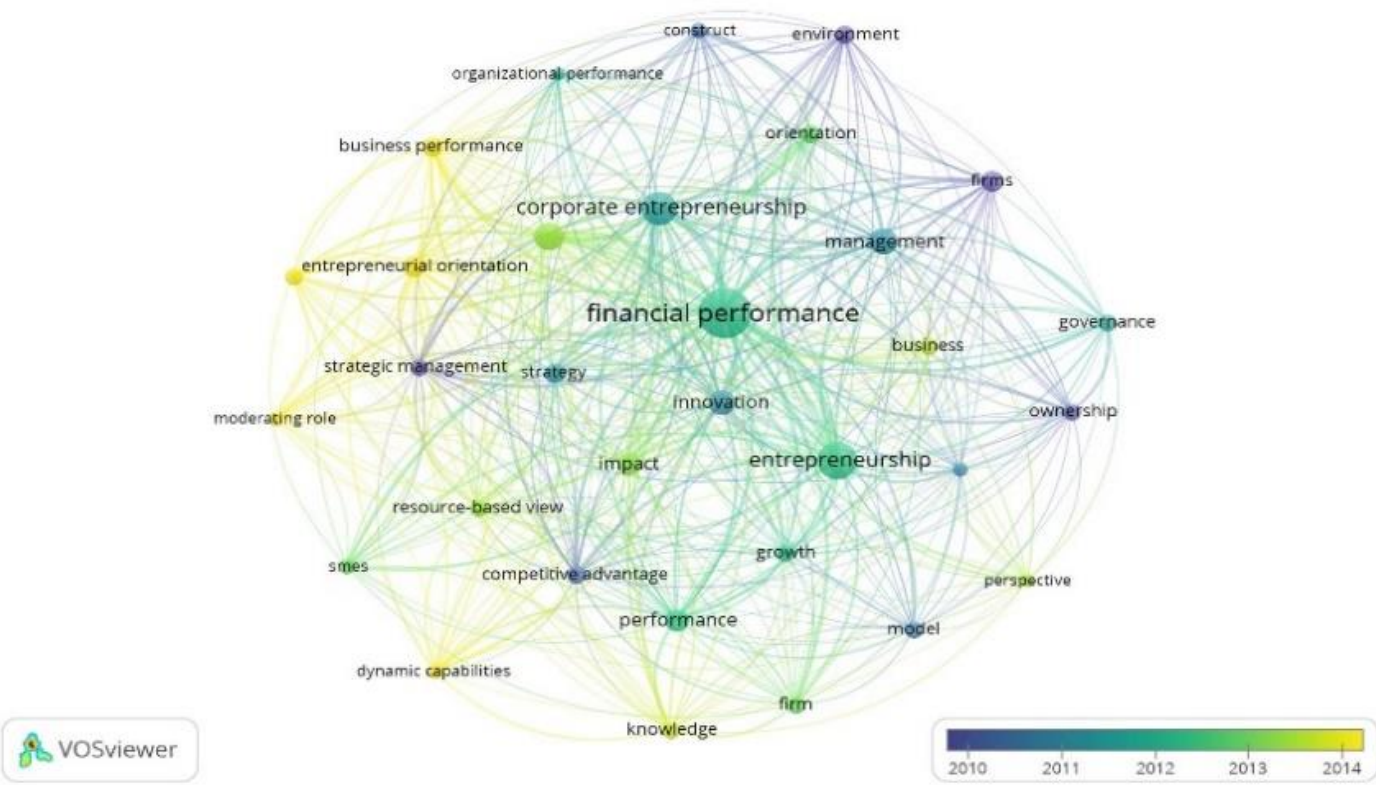

Figure 4. Keywords' co-occurrence

Source: made by the authors with VOSviewer 


\section{DISCUSSION}

According to the latest studies (Burgelman, 1988; Li, Zhao \& Liu, 2006; Gunday et al., 2011; Pantea, Gligor \& Anis, 2014; Senderovitz, Klyver \& Steffens, 2015; Bello et al., 2016; Begonja et al., 2016; Parida et al., 2016 Madison et al., 2018), the key to a successful business is influenced by several aspects: intra-entrepreneurship (entrepreneurial orientation), the ability of the company to create innovative products/services, digitalization, qualified employees and the management of economic factors (mainly recession).

Table 2. The centralized list of the 39 revised studies and the journals of publication

\begin{tabular}{|c|c|c|c|}
\hline Authors & Source & Authors & Source \\
\hline $\begin{array}{l}\text { Naman \& Slevin } \\
(1993)\end{array}$ & $\begin{array}{l}\text { Strategic Management } \\
\text { Journal }\end{array}$ & $\begin{array}{l}\text { Widya-Hasuti et al. } \\
(2018)\end{array}$ & Sustainability \\
\hline $\begin{array}{l}\text { Barringer \& Bluedorn } \\
\text { (1999) }\end{array}$ & $\begin{array}{l}\text { Strategic Management } \\
\text { Journal }\end{array}$ & $\begin{array}{l}\text { Yunis, El-Kassar \& } \\
\text { Tarhini (2017) }\end{array}$ & $\begin{array}{l}\text { Journal of Enterprise } \\
\text { Information Management }\end{array}$ \\
\hline Gunday et al. (2011) & $\begin{array}{l}\text { International Journal of } \\
\text { Production Economics }\end{array}$ & Zehir et al. (2016) & $\begin{array}{l}\text { 12th International Strategic } \\
\text { Management Conference, } \\
\text { ISMC 2016. Procedia - Social } \\
\text { and Behavioral Sciences }\end{array}$ \\
\hline $\begin{array}{l}\text { Menguc \& Ozanne } \\
(2005)\end{array}$ & $\begin{array}{l}\text { Journal of Business } \\
\text { Research }\end{array}$ & $\begin{array}{l}\text { Pantea, Gligor \& Anis } \\
\text { (2014) }\end{array}$ & $\begin{array}{l}\text { Challenges and Innovations in } \\
\text { Management and Leadership } \\
\text { 12th International Symposium } \\
\text { in Management }\end{array}$ \\
\hline Hayton (2003) & $\begin{array}{l}\text { Human Resource } \\
\text { Management }\end{array}$ & Seo et al. (2014) & Journal of Business Research \\
\hline Madsen (2007) & $\begin{array}{l}\text { Entrepreneurship and } \\
\text { Regional Development }\end{array}$ & $\begin{array}{l}\text { Cucculelli, Bettinelli } \\
\text { \& Renoldi (2014) }\end{array}$ & Management Decision \\
\hline Li, Zhao \& Liu (2006) & $\begin{array}{l}\text { International Journal of } \\
\text { Manpower }\end{array}$ & Arend et al. (2017) & Strategic Management Journal \\
\hline Kaya (2006) & $\begin{array}{l}\text { International Journal of } \\
\text { Human Resource } \\
\text { Management }\end{array}$ & $\begin{array}{l}\text { Son, Lee \& Chung } \\
\text { (2018) }\end{array}$ & Sustainability \\
\hline Schepers et al. (2014) & Small Business Economics & $\begin{array}{l}\text { Yunis, Tarhini \& } \\
\text { Kassar (2018) }\end{array}$ & Journal of Business Research \\
\hline Schmelter et al. (2010) & $\begin{array}{l}\text { Human Resource } \\
\text { Management }\end{array}$ & $\begin{array}{l}\text { Yeniaras \& Unver } \\
(2016)\end{array}$ & $\begin{array}{l}\text { European Management } \\
\text { Review }\end{array}$ \\
\hline $\begin{array}{l}\text { Vanacker, Collewaert } \\
\& \text { Paeleman (2013) }\end{array}$ & $\begin{array}{l}\text { Journal of Management } \\
\text { Studies }\end{array}$ & Begonja et al. (2016) & $\begin{array}{l}\text { Economic Research-Ekon } \\
\text { omska Istrazivanja }\end{array}$ \\
\hline Maes \& Sels (2014) & $\begin{array}{l}\text { Journal of Small Business } \\
\text { Management }\end{array}$ & Jiang et al. (2018) & Journal of Cleaner Production \\
\hline $\begin{array}{l}\text { Entrialgo, Fernandez \& } \\
\text { Vazquez (2000) }\end{array}$ & Technovation & Madison et al. (2018) & Journal of Business Research \\
\hline Bierwerth et al. (2015) & Small Business Economics & $\begin{array}{l}\text { Jin, Jung \& Jeong } \\
\text { (2017) }\end{array}$ & $\begin{array}{l}\text { International Entrepreneurship } \\
\text { and Management Journal }\end{array}$ \\
\hline Bello et al. (2016) & Journal of World Business & $\begin{array}{l}\text { Hernández-Perlines \& } \\
\text { Ibarra Cisneros (2017) }\end{array}$ & $\begin{array}{l}\text { Cogent Business \& } \\
\text { Management }\end{array}$ \\
\hline Kantur (2016) & Management Decision & Aloulou (2018) & $\begin{array}{l}\text { Middle East Journal of } \\
\text { Management }\end{array}$ \\
\hline Wu (2015) & $\begin{array}{l}\text { Journal of Business } \\
\text { Research }\end{array}$ & Xie \& Lv (2018) & $\begin{array}{l}\text { International Entrepreneurship } \\
\text { and Management Journal }\end{array}$ \\
\hline Parida et al. (2017) & $\begin{array}{l}\text { Entrepreneurship and } \\
\text { Regional Development }\end{array}$ & $\begin{array}{l}\text { Sahoo \& Yadav } \\
(2017)\end{array}$ & $\begin{array}{l}\text { Journal of Manufacturing } \\
\text { Technology Management }\end{array}$ \\
\hline $\begin{array}{l}\text { Senderovitz, Klyver \& } \\
\text { Steffens (2016) }\end{array}$ & $\begin{array}{l}\text { Journal-Researching } \\
\text { Entrepreneurship }\end{array}$ & $\begin{array}{l}\text { Courrent, Chasse \& } \\
\text { Omri (2018) }\end{array}$ & Journal of Business Ethics \\
\hline Su \& Sohn (2015) & $\begin{array}{l}\text { Asian Journal of } \\
\text { Technology Innovation }\end{array}$ & & \\
\hline
\end{tabular}


The 39 publications selected for analysis (Table 2) correlate entrepreneurial orientation with increasing financial performance, but also state that investing in employee training courses, stimulating creativity and flexibility in planning strategies to adapt to any risk are key influences in the evolution on the market of an enterprise.

The analysis shows several major factors that influence financial performance. Along with corporate entrepreneurship (entrepreneurial orientation, organizational culture, implementation of the managerial tools, risk taking) are found human resources, innovation, economic environment, digitalization (Figure 5).

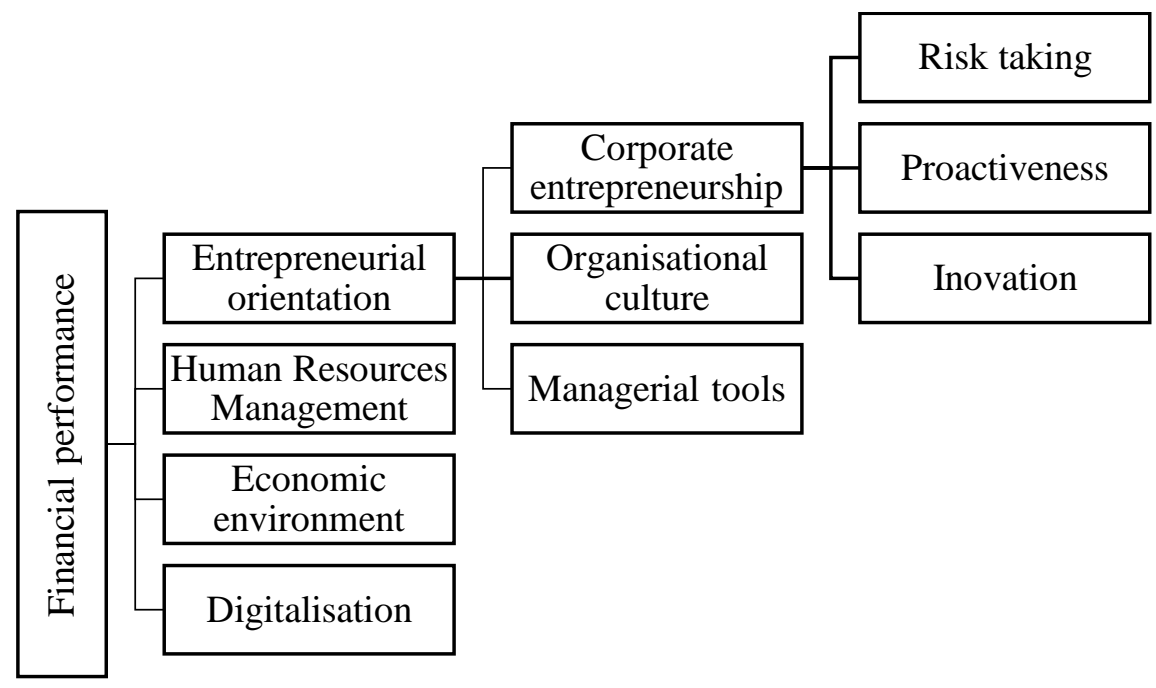

Figure 5. Key factors influenting the financial performance of a firm Source: made by the authors

\subsection{The influence of entrepreneurial orientation}

The entrepreneurial intensity of a company is influenced by the nature of its strategic management practices and its competitive strategy (Entriaglo, Fernández \& Vázquez, 2000; Sahoo \& Yadav, 2017). It is important to note the impact of competitive strategy compared to strategic practices on entrepreneurial orientation. From a strategy point of view, by comparison, companies that want to differentiate themselves on the market based on innovation are considered to have a more favorable internal environment for entrepreneurship than those who are reluctant to develop existing products/services (Entriaglo, Fernández \& Vázquez, 2000; Sahoo \& Yadav, 2017).

While entrepreneurs' orientation towards risk-taking directly improves their financial performance and ability to expand, strategic entrepreneurship increases the diversity of business products, creates new market opportunities and generates new ways of competing in the marketplace, and all this contributes to business well-being by increasing success (Kantur, 2016; Jin, Jung \& Jeong, 2017; Sahoo \& Yadav, 2017; Courrent, Chasse \& Omri, 2018). Consequently, entrepreneurial orientation incorporates innovation, risk-taking and proactivity, key elements in establishing the necessary context for entrepreneurial initiatives (Courrent, Chasse \& Omri, 2018) and by this, we agree that it also includes corporate entrepeneurship. 
Strategic orientation moderates the relationship between growth and profitability and is stronger for firms pursuing a broad market strategy, compared to a niche strategy (Senderovitz, Klyver \& Steffens, 2015).

Another favorable impact factor on a company's success is flexibility. According to some studies, enterprises should be more flexible in their planning systems (Barringer \& Bluedorn, 1999). Planning flexibility refers to the ease with which a company can change its strategic plan in response to the environmental changes. In practice, planning flexibility can be difficult to achieve because the number of companies allocating substantial financial resources to the development of short-term and long-term plans are increasing. As a result, in some cases, the magnitude of this effort can effectively act against firms, leading to a reluctance of managers to deviate from plans (Barringer \& Bluedorn, 1999). However, through a high level of employee involvement, regardless of the hierarchical level, in planning strategies, the results highlight this aspect as an essential key to the success of an enterprise (Burgelman, 1988). Lower level managers need to act freely in order to identify and pursue promising opportunities (Sathe, 1988). Top managers should focus their managerial attention on developing entrepreneurial orientation and educating other employees to act entrepreneurially within the company (by innovating new products and services and exploiting new opportunities to gain market advantages), especially if faces an extremely competitive environment. Moreover, senior managers should encourage employees to seek and create unusual ideas, but also to tolerate possible shortcomings by promoting entrepreneurship that promotes change and teamwork and encourage autonomous decisions (Aloulou, 2018).

Also, by implementing efficient control systems to evaluate the activity of employees and by creating systems to reward performance and creativity in the development of new innovative products/services we are positive of an increase of the financial performance of the enterprise (Madsen, 2007).

Continuing the results according to which flexibility is an important factor, we emphasize that poor strategic planning can negatively affect innovative activity and the return on investment. To the detriment of increasing the rate of financial return, the poor strategic planning can lead to losses (Arend et al., 2015). However, if management tools are used properly and the employees are proactive, there is a reduction in costs and an increase on the benefits.

As previously highlighted, the impact of the organizational environment and employees contributes to the success of an enterprise. But, at the same time, considering the economic context and also the legislative aspects, another important role is registered by the innovative capacity of the enterprise.

Researchers correlate the entrepreneurial orientation of innovation, explaining the positive impact by manifesting proactive behaviors of managers and improving external marketing as a result of increased risk tolerance (Bello et al., 2016).

Innovation is generally seen as an essential component of competitiveness, embedded in organizational structures, processes, products and services within an enterprise (Gunday et al., 2011; Su \& Sohn, 2015). A clear understanding of the exact nature of innovations helps companies to prioritize their market and production strategies and technological potential, followed by an appropriate strategy. The performance obtained on the basis of innovation is conditioned by the resources available to the company. For the enterprises that encourage the 
implementation of high-level innovative activities there is an increase in market shares, total sales and higher exports (where the activity is of this nature), and, implicitly, a significant improvement in the financial performance indicators, the most significant measure for success (Gunday et al., 2011; Su \& Sohn, 2015; Bello et al., 2016).

The lack of investment in innovative projects is equal to a failure because if there is no investment made in any form of innovation, there is reduction of the efficiency of the enterprises in introducing new or improved products/processes and can cause the company to miss the advantages offered by the market (Maes \& Sels, 2013). Radically innovative enterprises play a key role in the economy by developing and exploiting new products, technologies and services that can change the structures of that economy and increase the attractiveness of the region's economy.

Recent studies on innovation correlate the success and prosperity of enterprises with their strong propensity to exploit opportunities in high-risk environments and the development of green products/services (Menguc \& Ozanne, 2005).

The results show that innovation-oriented social entrepreneurs perceive higher business performance than their competitors and are able to achieve higher performance results than traditional and non-innovative innovators (Begonja et al., 2016). The introduction of product or process innovation and social innovation are significantly related to maximizing business performance (Son, Lee \& Chung 2018) and vice versa and emphasize the reciprocity of the relationship between enterprise success and the introduction of innovation (Begonja et al., 2016). In social enterprises, research results show that product innovation attributes based on simplicity, utility and standardization of the product/service have a critical influence on added value (Son, Lee \& Chung, 2018).

However, the size of the enterprise impacts the magnitude of innovation through the resources available to the enterprise. Smaller firms typically manage limited resources, while larger firms have allocated more financial, organizational, and human resources (Bierwerth et al., 2015). In case of investment failure, the amount of resources allocated to product or process innovation, but also the size of the enterprise determines the ability to absorb the failure and its survival (Widya-Hasuti et al, 2018).

\subsection{The influence of human resources management}

Performance has been shown to be influenced in some extent by the human resources of an enterprise, which is in line with current research trends, that links human resource practices with revenue growth (Pantea, Gligor \& Anis, 2014). The results show that human resources are a valuable source in terms of strategic advantages and improved financial performance (Hayton, 2003). In addition, it was confirmed that a good management of human resource (HRM) practices by which employers focus on behavior and attitude, intensive training courses, on-the-job skills training, written procedures, activities in team, training in multiple functions, incentive to achieve objectives, communication of strategy, interaction facilitates, feedback on performance contributes to improving the performance of the enterprise, respectively, to the success of the enterprise (Schmelter et al., 2010; Courrent, Chasse \& Omri, 2018). Specifically, HRM practices contribute in creating value, sustain the competitive advantage, and improve the enterprise performance (Hayton, 2003; Kaya, 2006). 
In a company in which the objectives are oriented in developing an entrepreneurial environment, where employees are more proactive, managers encourage innovation and risk-taking, and have a more aggressive competitive policy, the strategic human resources activities will automatically transform to provide the necessary support. Through sufficient training programs for the employees, competitive compensation and reward systems for the employees the long-term goals and strategies are more likely to be achieved (Zehir et al., 2016). As a result, the contribution of human capital in increasing the company's performance is expected to increase automatically if those requirements are met. Those actions are linking HRM to the corporate entrepreneurship and are also highlighting their interconnectivity.

However, although the efficiency and professionalization of human resources management can lead to increasing the financial performance of a company, the deepening of research conducted at the level of family businesses has shown that the implementation of these practices has an impact on how family and non-family employees are treated. It has been noted in these enterprises the reduction of moral hazard and the perception of injustice at the organizational level as a result of equal levels of monitoring between family and family employees (Madison et al., 2018). When employees who are family members are not monitored, there is a prejudice about equal treatment. In other words, we suggest that the absence of equal treatment bias is another possible explanation for the positive effects observed on business performance. There are also family businesses that, if they innovate in environmental aspects, register higher financial performances (HernándezPerlines \& Ibarra Cisneros, 2017)

\subsection{The influence of the economic environment}

Deepening the analysis from the point of the influence of the economic environment, we found that during a recession, investments in intangible assets generate a stabilizing effect. Market share and leverage moderate the effects of investment in research and development (R\&D) and advertising (ie intangible assets) on performance. Also, changes in business models are considered to be an important factor explaining performance (Cucculelli, Bettinelli \& Renoldi, 2014). The negative influence of leverage on performance is best explained by the uncertainty caused by the recession which can reduce the ability of the intangible assets to react to changes in demand. This is mainly the case when a company's financial resources and strategic choices are constrained by the economic downturn. However, the impact on the company's performance increases with the investment in intangible assets, $R \& D$ and marketing; implicitly increasing the market share of the enterprise (Bierwerth et al., 2015). This change in performance is due to a change in the company's business model. The importance of intangible assets during recessions is also supported by studies indicating that investment in research and development and marketing has positive effects on profitability (Bierwerth et al., 2015).

Following the highlighted results, studies aimed at another form of entrepreneurship (franchising), supporting the increase of the financial performance obtained through marketing (exchange of knowledge, trust, managing the conflicts and brand reputation). In the case of these cases of companies, the brand reputation plays an important role in the processes of building relationships and is the main factor contributing to the success of franchises ( $\mathrm{Wu}, 2015)$.

Given the fact that the economic environment is associated with a fast changing rhythm in which the strengths of a firm can easily become a liability, we must outline another factor to the activity of a firm. With this in mind, depending on the environmental level of competitiveness, we emphasize the importance of innovation in high levels of competitiveness and in low medium of 
competitiveness environmental studies highlight the importance of balancing the marketing activity and innovation process (Yeniaras \& Unver, 2016).

It is important to note another factor that influences the financial performance of a company, meaning the trend of the green development market. Adopting a green entrepreneurial orientation has become a critical approach for companies wishing to maintain their competitive advantage, and studies show that the entrepreneurial orientation towards green development has positive influences on both environmental and financial performance (Jiang et al., 2018).

Deepening the analysis from the point of market transparency, we mention that although it is easy to see from the profit and loss account what happens within a company, there are studies (Schepers et al., 2013) that claims that increasing sales is only a step towards business success (profitability) and entrepreneurship orientation, which is described almost universally as a contribution to growth, does not automatically make the company profitable. Previous research on the resources available to some entrepreneurs has argued that both external investors and angel investors increase the value of the firm by lowering costs for entrepreneurs and increasing the performance of private equity firms (Vanacker, Collewaert \& Paeleman, 2013). Institutional support could also reduce dependence on the external environment, and by strengthening ties with the government and obtaining institutional support, companies can compensate for the lack of resources. Some studies argue that greater institutional support for entrepreneurs can balance the challenges they face (Xie \& Lv, 2018).

\subsection{The influence of digitalisation}

Innovations and applications based on information and communication technologies (ICT) have become major drivers in the process of enhancing the organizational performance, the economic growth and the social change (Yunis, Tarhini \& Kassar, 2018).

Research has shown that information and communication technologies (ICT) are crucial for economic growth because ICT innovation is considered a strategic resource (Yunis, El-Kassar, \& Tarhini, 2017). When an enterprise wants to gain a competitive advantage in an uncertain economic environment, technological innovation is positively related to their performance $(\mathrm{Li}$, Zhao \& Liu, 2006; Yunis, El-Kassar, \& Tarhini, 2017). Given that technological innovation in enterprises has an important influence on performance, it is necessary to train employees to develop the knowledge needed to adapt to the technology. Given the fact that entrepreneurship is seen as the engine of growth (Yunis, Tarhini \& Kassar, 2018), it is important that the magnitude of such an investment is fully understood. Employee training helps high-tech enterprises to gain not only technological progress through the knowledge of subordinate employees, but also to find new opportunities in the market and increase their capacity for innovation by exchanging information and improving skills ( $\mathrm{Li}$, Zhao \& Liu, 2006). In support of these claims, existing empirical studies state that effective human resource management is needed to successfully implement sustainable technological innovation. Therefore, in order to achieve higher performance results, high-tech enterprises, with a strong emphasis on innovation, ensure sales performance compared to non-innovative enterprises due to the marketing of new products and services on a regular basis (Parida et al., 2016; Yunis, Tarhini \& Kassar, 2018).

It has been shown that in entrepreneurial environments, where appropriate strategies are applied and the ICT is used correctly, statistics show that those factors can improve performance and they can also lead to a sustained competitive advantage (Yunis, Tarhini \& Kassar, 2018). In other 
words, investments in ICT cannot be developed in isolation from the company's strategies, direction, mission and objectives; they are the catalyst that will shape ICT resources, organizational processes and employee knowledge in new resources, capabilities and current initiatives (Yunis, El-Kassar, \& Tarhini, 2017).

The phenomenon of digitization manifests itself in a way that encourages and applies proactivity, innovation and risk-taking and is inevitably present in the market (Yunis, El-Kassar, \& Tarhini, 2017; Yunis, Tarhini \& Kassar, 2018). The broad role of ICT benefits comes from the fact that the innovative use of ICT contributes to the market differentiation of competitive and noncompetitive firms. It is important to note that early implementation of technological innovations generates huge benefits and delays or non-adoption of technology innovations can reduce firms' performance (El-Kassar, \& Tarhini, 2017; Yunis, Tarhini \& Kassar, 2018).

Thus, by deepening this drivers' impact on the financial performance, we can state that all the mentioned drivers are intercorrelated and by stating this, we confirm the theory that corporate entrepreneurship is corelated to all the major drivers.

\section{CONCLUSIONS}

Entrepreneurship studies are a growing topic of interest for both senior management, entrepreneurs and other researchers in the field of entrepreneurship.

As the goal for any business is to use available resources to maximize the value of the profit, an important part of any business is the ability to obtain the financial performance with every action taken while remaining competitive.

In the evaluation of an enterprises' performance, the conducted research has led to the conclusion that a key role is considered to be played by corporate entrepreneurship. We must also mention that some researchers consider corporate entrepreneurship as a integrated part of the entrepreneurial orientation, and we agree with them.

Starting with 2015, the number of studies aimed at maximizing the profit of companies and influencing factors is increasing, and the top three regions with the most contribution in this field of analysis are England, USA, China and Spain. The variation of the keywords used during the analysed period indicates the changes and orientations of the researches that vary from "strategic management", "model", "ownership", "environment" (in 2010), to those that focus on "business", "entrepreneurial orientation", "knowledge", "dynamic capabilities", "moderating role".

The study found that corporate entrepreneurship encompasses formal and informal activities and is a process used in discovering and developing opportunities, products/services/processes through strategic renewal and innovation and by forming entrepreneurial thinking. The research results indicate corporate entrepreneurship as having a multidimensional structure consisting of four key elements: risk-taking, innovation, proactivity and competitive aggression.

It was also found that although corporate entrepreneurship is the new trend in the style of management within the companies, its interconnectivity with the major known drivers should not be omitted: nurturing the human resource, the economic environment and digitalization. 
The theoretical implications of the presented paper provide for future researchers and scholars interested in deepening this field with a systemized base. Given the novelty of corporate entrepreneurship and the implications of the other existing factors (internal and external) that can easily mark enterprises, we also analyzed corporate entrepreneurship's impact in increasing the financial performance among side with the interconnectivity with some other drivers already known to have an impact on enterprises incomes.

Moreover, alongside presenting the current situation of the existing written publications related to corporate entrepreneurship, we also want to highlight new possibilities to continue this research starting from our quantitative analysis of the scientific literature existing in Web of Science in this field and identifying the most appropriate journals to publish the future results of their studies.

This research is one of the few papers which explore the actual state of the published articles carried out on the correlation between corporate entrepreneurship and financial performance and other known drivers, based on a mix set of analysis.

Regarding the limitations of the research, it should be noted that this is caused by the fact that the analysis uses information extracted from a single database (Web of Science), which has been filtered numerous times (by selecting only the papers published in English, framed in a certain research area, that used certain keywords of interest). Also, by doing this filtering there was the possibility of excluding important papers related to the analysed subject.

\section{ACKNOWLEDGEMENTS}

This study is the result of the research carried out within the doctoral studies programs of the Bucharest University of Economic Studies, Doctoral School of Management.

\section{REFERENCES}

Aloulou, W.J. (2018). Studying the influences of learning orientation and firm size on entrepreneurial orientation - firm performance relationship in Saudi context. Middle East Journal of Management, 5(2), 137. https://doi.org/10.1504/mejm.2018.10012115

Archambault, É., Campbell, D., Gingras, Y. \& Larivière, V. (2009). ComparingBibliometric Statistics Obtained from the Web of Science and Scopus. Journal of the Association for Information Science and Technology, 60 (7), 1320-1326. https://doi.org/10.1002/asi.21062

Arend, R.J., Zhao, Y.L., Song, M., \& Im, S. (2015). Strategic planning as a complex and enabling managerial tool. Strategic Management Journal, 38(8), 1741-1752. https://doi.org/10.1002/smj.2420

Barringer, B.R. \& Bluedorn, A.C. (1999). The relationship between corporate entrepreneurship and strategic management. Strategic Management Journal, 20 (5), 421-444. https://doi.org/10.1002/(sici)1097-0266(199905)20:5<421::aid-smj30>3.0.co; 2-o

Becker, M.C. (2004).Organizational routines: a review of the literature. Industrial and Corporate Change, 13(4). https://doi.org/10.1093/icc/dth026

Begonja, M., Čićek, F., Balboni, B., \& Gerbin, A. (2016). Innovation and business performance determinants of SMEs in the Adriatic region that introduced social innovation. Economic Research-Ekonomska Istraživanja, 29(1), 1136-1149. https://doi.org/10.1080/1331677x. 2016.1213651

Bello, D.C., Radulovich, L.P., Javalgi, R. (Raj) G., Scherer, R.F., \& Taylor, J. (2016). Performance of professional service firms from emerging markets: Role of innovative 
services and firm capabilities. Journal of World Business, 51(3), 413-424. https://doi.org/10.1016/j.jwb.2015.11.004

Berbegal-Mirabent, J., Alegre, I. \& Ribeiro-Soriano, D. (2018). Entrepreneurship in the Middle East and North Africa: A Bibliometric Analysis. Nezameddin Faghih, Mohammad Reza Zali (editors): Entrepreneurship Education and Research in the Middle East and North Africa (MENA), Springer, Cham, 273-290. https://doi.org/10.1007/978-3-319-90394$1 \_15$

Bierwerth, M., Schwens, C., Isidor, R., \& Kabst, R. (2015). Corporate entrepreneurship and performance: A meta-analysis. Small Business Economics, 45(2), 255-278. https://doi.org/ 10.1007/s11187-015-9629-1

Bourcet, C. (2019). Empirical determinants of renewable energy deployment:A systematic literature review. Energy Economics, 85, 104563. https://doi.org/10.1016/j.eneco. 2019.104563

Burgelman, R.A. (1998). Strategy making as a social learning process:the case of internal corporate venturing. Interfaces, 18(3), 74-85. https://doi.org/10.1287/inte.18.3.74

Burja, C. \& Burja, V. (2013). Entrepreneurial risk and performance: empirical evidence of Romanian agricultural holdings. Annales Universitatis Apulensis Series Oeconomica, 2(15), 561-569. https://doi.org/10.29302/oeconomica.2013.15.2.21

Chițimiea, A., Ciocoiu, C.N., Prioteasa, A.L. \& Marin, A.A. (2020b). A Bibliometric Analysis of the Link Between Risk Management and Performance in Entrepreneurship. Ondřej Dvouletý, Martin Lukeš \& Jan Mísař (editors): Proceedings of the 8th International Conference: Innovation Management, Entrepreneurship and Sustainability, Prague, Czech Republic.

Chițimiea, A., Ciocoiu, C.N., Stoica, B.Ș. \& Prioteasa, A.L. (20202a). Bibliometric Assessment of Research on Risk Attitude of Entrepreneurs. Management, 15(1), 3-27. https://doi.org/10.26493/1854-4231.15.3-27

Courrent, J.-M., Chassé, S. \& Omri, W. (2016). Do Entrepreneurial SMEs Perform Better Because They are More Responsible? Journal of Business Ethics, 153(2), 317-336. https://doi.org/10.1007/s10551-016-3367-4

Crossan, M.M., \&Apaydin, M. (2009). A Multi-Dimensional Framework of Organizational Innovation: A Systematic Review of the Literature. Journal of Management Studies, 47(6), 1154-1191. https://doi.org/10.1111/j.1467-6486.2009.00880.x

Cucculelli, M., Bettinelli, C. \& Renoldi, A. (2014). How small-medium enterprises leverage intangibles during recessions. Evidence from the Italian clothing industry. Management Decision, 52(8), 1491-1515. https://doi.org/10.1108/md-01-2014-0034

Dabić, M., Maley, J., Dana, L.P., Novak, I. Pellegrini M.M. \& Caputo A. (2020). Pathways of SME internationalization: a bibliometric and systematic review. Small Business Economic, 55, 705-725. https://doi.org/10.1007/s11187-019-00181-6

Dan, M.C. \& Goia, S.I. (2018). Entrepreneurship and regional development. A bibliometric analysis. Proceedings of the $12^{\text {th }}$ International Conference on Business Excellence, Bucharest, Romania. https://doi.org/10.2478/picbe-2018-0025

Dionisio, M. (2019) The evolution of social entrepreneurship research: a bibliometric analysis. Social Enterprise Journal, 15(1), 22-45. https://doi.org/10.1108/SEJ-05-2018-0042

Entriaglo, E., Fernández, E. \& Vázquez, C.J. (2000). Linking entrepreneurship and strategic management: evidence from Spanish SMEs. Technovation, 20 (8), 427-436. https://doi.org/10.1016/s0166-4972(99)00168-6

Gonzalez-Loureiro, M., Dabić, M., \& Furrer, O. (2015). A content and comparative analysis of strategic management researchin the Baltic area: a research agenda for qualitative studies. 
Baltic Journal of Management, 10 (2), 243-266. https://doi.org/10.1108/bjm-12-20130187

Goosen, C.J., De Coning, T.J. \& Smit, E.V.D.M. (2002). Corporate entrepreneurship and financial performance: The role of management. South African Journal of Business Management, 33(4), 21-27. https://doi.org/10.4102/sajbm.v33i4.708

Gora, A.A. (2019). The Link Between Decision making Process and Performance: A Bibliometric Analysis. Management and Economics Review, 4(2), 177-191, https://doi.org/10.24818/mer/2019.12-08

Gunday, G., Ulusoy, G., Kilic, K. \& Alpkan, L. (2011). Effects of innovation types on firm performance. International Journal of Production Economics, 133(2), 662-679. https://doi.org/10.1016/j.ijpe.2011.05.014

Guth, W.D. \& Ginsberg, A. (1990). Guest editors' introduction: Corporate entrepreneurship. Strategic Management Journal, 11(4), 5-15. Retrieved, July 20, 2020, from http://www.jstor.org/stable/2486666

Hallinger, P. (2013). A conceptual framework for systematic reviews of research in educational leadership and management. Journal of Educational Administration, 51 (2), 126-149. https://doi.org/10.1108/09578231311304670

Hayton, J.C. (2003). Strategic human capital management in SMEs An empirical study of entrepreneurial performance. Human Resource Management, 42(4), 375-391. https://doi.org/10.1002/hrm.10096

Hernández-Perlines, F. \& Ibarra Cisneros, M.A. (2017). Analysis of the moderating effect of entrepreneurial orientation on the influence of social responsibility on the performance. Cogent Business \& Management, 4(1), 1408209, https://doi.org/10.1080/23311975. 2017.1408209

Jiang, W., Chai, H., Shao, J. \& Feng, T. (2018). Green entrepreneurial orientation for enhancing firm performance A dynamic capability perspective. Journal of Cleaner Production, 198, 1311-1323. https://doi.org/10.1016/j.jclepro.2018.07.104

Jin, B., Jung, S., \& Jeong, S.W. (2017). Dimensional effects of Korean SME's entrepreneurial orientation on internationalization and performance. International Entrepreneurship and Management Journal, 14, 195-215. https://doi.org/10.1007/s11365-017-0457-4

Kantur, D. (2016). Strategic entrepreneurship: mediating the entrepreneurial orientationperformance link. Management Decision, 54(1), 24-43. https://doi.org/10.1108/MD-112014-0660

Karacaoglu, K., Bayrakdaroglu, A., \& San, F.B. (2012). The Impact of Corporate Entrepreneurship on Firms' Financial Performance: Evidence from Istanbul Stock Exchange Firms. International Business Research, 6(1). https://doi.org/10.5539/ibr. v6n1p163

Karpak, B. \& Topcu, I. (2010). Small medium manufacturing enterprises in Turkey: an analytic network process framework for pioritizing factors affecting success. International Journal of Production Economics, 125(1), 60-70. https://doi.org/10.1016/j.ijpe.2010.01.001

Kaya, N. (2006). The impact of human resource management practices and corporate entrepreneurship on firm performance: evidence from Turkish firms. The International Journal of Human Resource Management, 17(12), 2074-2090. http://dx.doi.org/10.1080/ 09585190601000204

Kraus, S. \& Kauranen, I. (2009). Strategic management and entrepreneurship: friends or foes? International Journal of Business Science and Applied Management, 4(1), 37-50. Retrieved July 30, 2020, from https://www.semanticscholar.org/paper/Strategicmanagement-and-entrepreneurship\%3A-Friends-Kraus-Kauranen/ff6a43da0fe3c61 ecbd 7 ba567c555baf75505185 
Kuratko, D.F., Ireland, R.D. \& Hornsby, J.S. (2004). Corporate entrepreneurship behaviour among managers: A review of theory, research, and practice. Advances in Entrepreneurship, Firm Emergence and Growth, 7(04), 7-45. https://doi.org/10.1016/ s1074-7540(04)07002-3

Kwak, H., Jaju, A., Puzakova, M., \& Rocereto, J.F. (2013). The connubial relationship between market orientation and entrepreneurial orientation. The Journal of Marketing Theory and Practice, 21(2), 141-162. https://doi.org/10.2753/MTP1069-6679210202

Lampe, J., Kraft, P.S. \& Bausch, A. (2019). Mapping the Field of Research on Entrepreneurial Organizations (1937-2016): A Bibliometric Analysis and Research Agenda. Entrepreneurship Theory and Practice. 1-33, https://doi.org/10.1177/1042258719851217

Li, Y., Zhao, Y., \& Liu, Y. (2006). The relationship between HRM, technology innovation and performance in China. International Journal of Manpower, 27(7), 679-697. https://doi.org/10.1108/01437720610708284

Lumpkin, G.T. \& Dess, G.G. (1996). Clarifying the entrepreneurial orientation construct and linking it to performance. Academy of Management Review, 21(1), 135-172. https://doi.org/10.5465/amr.1996.9602161568

Madison, K., Daspit, J.J., Turner, K. \& Kellermanns, F.W. (2018). Family firm human resource practices: Investigating the effects of professionalization and bifurcation bias on performance. Journal of Business Research, 84, 327-336. https://doi.org/10.1016/ j.jbusres.2017.06.021

Madsen, E.L. (2007). The significance of sustained entrepreneurialorientation on performance of firms - A longitudinal analysis. Entrepreneurship \& Regional Development: An International Journal, 19(2), 185-204. https://doi.org/10.1080/08985620601136812

Maes, J. \& Sels, L. (2013). SMEs' Radical Product Innovation The Role of Internally and Externally Oriented Knowledge Capabilities. Journal of Small Business Management, 52(1), 141-163. https://doi.org/10.1111/jsbm.12037

Menguc, B., \& Ozanne, L.K. (2005). Challenges of the "green imperative": a natural resourcebased approach to the environmental orientation-business performance relationship. Journal of Business Research, 58(4), 430-438. http://dx.doi.org/10.1016/ j.jbusres.2003.09.002

Miller, D. \& Breton-Miller, L. (2011). Governance, social identity and entrepreneurial orientation in closely held public companies. Entrepreneurship Theory and practice, 35(5), 1051-1076. https://doi.org/10.1111/j.1540-6520.2011.00447.x

Miller, D. \& Friesen, P.H. (1978). Archetypes of strategy formulation. Management Science, 24(9), 921-933. http://dx.doi.org/10.1287/mnsc.24.9.921

Niewoudt, S. (2016). Entrepreneurial characteristics and financial performance (Paper submitted for degree at Master of Science in Agricultural Economics, University of the Free State Bloemfontein, 2016). Retrieved from https://scholar.ufs.ac.za/handle/ $11660 / 4021$

Otache, I. \& Mahmood, R. (2015). Corporate Entrepreneurship and Business Performance: The Role of External Environment and Organizational Culture: A Proposed Framework. Mediterranean Journal of Social Sciences. http://dx.doi.org/10.5901/mjss. 2015.v6n4s3p524

Pantea, M., Gligor, D. \& Anis, C. (2014). Economic Determinants of Romanian Firms' Financial Performance. Procedia - Social and Behavioral Sciences, 124, 272-281. https://doi.org/10.1016/j.sbspro.2014.02.486

Parida, V., Pesämaa, O., Wincent, J. \& Westerberg, M. (2016). Network capability, innovativeness, and performance: a multidimensional extension for entrepreneurship. 
Entrepreneurship \& Regional Development, 29(1-2), 94-115. https://doi.org/10.1080/ 08985626.2016 .1255434

Rauch, A., Wiklund, J., Lumpkin, G.T., \& Frese, M. (2009). Entrepreneurial orientation and business performance: An assessment of past research and suggestions for the future. Entrepreneurship Theory and Practice, 33(3), 761-787. https://doi.org/10.1111/j.15406520.2009.00308.x

Reijonen, H., Hirvonen, S., Nagy, G., Laukkanen, T., \& Gabrielsson, M. (2015). The impact of entrepreneurial orientation on B2B branding and business growth in emerging markets. Industrial Marketing Management, 51, 35-46. https://doi.org/10.1016/j.indmarman .2015.04.016

Rey-Martí, A., Ribeiro-Soriano, D., \& Palacios-Marqués, D. (2016). A bibliometric analysis of social entrepreneurship. Journal of Business Research, 69(5), 1651-1655. https://doi.org/10.1016/j.jbusres.2015.10.033

Rutherford, M.W. \& Holt, D.T. (2007). Corporate entrepreneurship: An empirical look at the innovativeness dimension and its antecedents. Journal of Organizational Change Management, 20(3), 429-446. https://doi.org/10.1108/09534810710740227

Sahoo, S. \& Yadav, S. (2017). Entrepreneurial orientation of SMEs, total quality management and firm performance. Journal of Manufacturing Technology Management, 28(7), 892-912. https://doi.org/10.1108/jmtm-04-2017-0064

Sathe, V. (1988). From surface to deep corporate entrepreneurship. Human Resource Management, 27 (4), 389-411. https://doi.org/10.1002/hrm.3930270403

Schepers, J., Voordeckers, W., Steijvers, T. \& Laveren, E. (2013). The entrepreneurial orientation-performance relationship in private family firms: the moderating role of socioemotional wealth. Small Business Economics, 43(1), 39-55. https://doi.org/ $10.1007 / \mathrm{s} 11187-013-9533-5$

Schmelter, R., Mauer, R., Börsch, C. \& Brettel, M. (2010). Boosting corporate entrepreneurship through HRM practices Evidence from German SMEs. Human Resource Management, 49(2), 715-741. https://doi.org/10.1002/hrm.20366

Senderovitz, M., Klyver, K., \& Steffens, P. (2015). Four years on: Are the gazelles still running? A longitudinal study of firm performance after a period of rapid growth. International Small Business Journal: Researching Entrepreneurship, 34(4), 391-411. https://doi.org/10.1177/0266242614567483

Seo, J.H., Perry, V.G., Tomczyk, D., \& Solomon, G.T. (2014). Who benefits most The effects of managerial assistance on high- versus low-performing small businesses. Journal of Business Research, 67(1), 2845-2852. https://doi.org/10.1016/j.jbusres.2012.07.003

Servantie, V., Cabrol, M., Guieu, G. \&Boissin, J.P. (2016).Is international entrepreneurship a field? A bibliometric analysis of the literature (1989-2015). Journal of International Entrepreneurship,14(2), 168-212. https://doi.org/10.1007/s10843-015-0162-8

Sharma, P. \& Chrisman, J.J. (1999). Toward a reconciliation of the definitional issues in the field of corporate entrepreneurship. Entrepreneurship Theory and Practice, 23(3), 11-27. Retrived July 25, 2020 from https://cemi.com.au/sites/all/publications/Sharma\%20and \%20Chrisman\%201999.pdf

Son, H., Lee, J. \& Chung, Y. (2017). Value Creation Mechanism of Social Enterprises in Manufacturing Industry Empirical Evidence from Korea. Sustainability, 10(1), 46. https://doi.org/10.3390/su10010046

Song, J., Zhang, H. \& Dong, W. (2016). A Review of Emerging Trends in Global Research: Analysis and Visualization. Scientometrics, 107(3), 1111-1147. https://doi.org/10.1007/ s11192-016-1918-1 
Su, D.-J. \& Sohn, D.-W. (2015). Roles of entrepreneurial orientation and guanxi network with parent university in start-ups' performance: evidence from university spin-offs in China. Asian Journal of Technology Innovation, 23(1), 1-19. https://doi.org/10.1080/ 19761597.2015.1008196

Umrani, W.A., Kura, K.M., \& Ahmed, U. (2018). Corporate entrepreneurship and business performance. PSU Research Review, 2(1), 59-80. https://doi.org/10.1108/prr-12-20160011

Vanacker, T., Collewaert, V. \& Paeleman, I. (2013). The Relationship between Slack Resources and the Performance of Entrepreneurial Firms: The Role of Venture Capital and Angel Investors. Journal of Management Studies, 50(6), 1070-1096. https://doi.org/ 10.1111/joms.12026

Voorberg, W.H., Bekkers, V.J.J.M., \& Tummers, L.G. (2015) A Systematic Review of CoCreation and Co-Production: Embarking on the social innovation journey. Public Management Review, 17(9), 1333-1357. https://doi.org/10.1080/14719037.2014.930505

Walker, E., \& Brown, A. (2004). What success factors are important to small business owners? International Small Business Journal, 22(6), 577-594. https://doi.org/10.1177/ 0266242604047411

Wang, C.L. (2008). Entrepreneurial orientation, learning orientation, and firm performance. Entrepreneurship Theory and Practice, 44(0), 635-657. https://doi.org/10.1111/j.15406520.2008.00246.x

Widya-Hasuti, A., Mardani, A., Streimikiene, D., Sharifara, A. \& Cavallaro, F. (2018). The Role of Process Innovation between Firm-Specific Capabilities and Sustainable Innovation. Sustainability, 10(7), 2244. https://doi.org/10.3390/su10072244 